\title{
INVESTIGATION OF CONDITIONS FOR PROVIDING LOW CONTENT OF DIFFUSION HYDROGEN IN WELDING USING ELECTRODES OF BASIC TYPE
}

\author{
A.P. PALTSEVICH \\ E.O. Paton Electric Welding Institute, NASU \\ 11 Kazimir Malevich Str., 03680, Kiev, Ukraine. E-mail: office@paton.kiev.ua
}

\begin{abstract}
In this work the mechanisms for prevention of hydrogen absorption at the participation of $\mathrm{CaF}_{2}$ and $\mathrm{SiO}_{2}$ in submerged arc welding and welding with covered electrodes resulting in formation of HF, based on thermodynamic calculations, are considered. The formation of $\mathrm{SiF}_{4}$ and $\mathrm{HF}$ was experimentally established in the air samples in the arc zone. In the opinion of researchers, HF is a thermally resistant compound in the arc gap and, thus, it facilitates the decrease of $P_{\mathrm{H}}$ in the arc zone. As the criterion for the efficiency of this mechanism the reduction and elimination of weld porosity in submerged arc welding were served. The further works and accurate data on thermal properties of $\mathrm{HF}, \mathrm{H}_{2}, \mathrm{H}_{2} \mathrm{O}$, $\mathrm{N}_{2}$ and other gases at high temperatures, as well as the results of experiments with measurement of $[\mathrm{H}]_{\text {diff }}$ content in welds showed that the above-mentioned mechanism does not provide the ultra-low $[\mathrm{H}]_{\text {diff }}$ content. In the present work the investigations on the influence of $\mathrm{CaF}_{2}$ and moisture content in the coating on $[\mathrm{H}]_{\text {diff }}$ content were carried out, the content of water impurities was determined in the components of electrode coatings at heating up to $1000{ }^{\circ} \mathrm{C}$. It is shown that the preliminary heat treatment of the components provides reduction of the level of $[\mathrm{H}]_{\text {diff }}$ to $\leq 3-2 \mathrm{ml} / 100 \mathrm{~g}$ depending on the coating composition. 19 Ref., 3 Tables, 5 Figures.
\end{abstract}

Keywords: arc welding, covered electrodes, potential hydrogen, diffusion hydrogen, silicon fluoride, hydrogen fluoride, dissociation of gases, components of electrode coatings, chromatographic analysis of hydrogen, investigations

Hydrogen is the undesirable impurity in the weld metal, because it leads to formation of porosity and is one of the causes for cold crack formation in welded joints of high-strength low-alloyed steels.

In accordance with the IIW standards, the electrodes are classified according to the content of hydrogen introduced to the deposited metal or diffusion hydrogen $[\mathrm{H}]_{\text {diff d.m: }}$ : up to $5 \mathrm{ml} / 100 \mathrm{~g}$ as very low, up to $10 \mathrm{ml} / 100 \mathrm{~g}$ - low hydrogen, up to $15 \mathrm{ml} / 100 \mathrm{~g}$ - middle hydrogen ones. In accordance with the AWS standards, the levels of $[\mathrm{H}]_{\text {diff d.m }}$ amount to $2,4,8,16 \mathrm{ml} / 100 \mathrm{~g}$. The following methods of analysis are used: according to standard ISO 36902000E, mercury-vacuum (primary) chromatography (express) due to reduced time of the analysis to $6 \mathrm{~h}$ at temperature of $150{ }^{\circ} \mathrm{C}$; according to standard ANS/ AWS-A.4-93, chromatographic analysis for $6 \mathrm{~h}$ at $150{ }^{\circ} \mathrm{C}$. It should be noted that the use of alcohol or glycerin samples does not give a real idea of the $[\mathrm{H}]$ diff d.m content, because these procedures give lowered results.

The problem of providing the level of $[\mathrm{H}]_{\text {diff d.m }}<$ $<5$ and, moreover, $\leq 3$ and $2 \mathrm{ml} / 100 \mathrm{~g}$ is not solved completely and is urgent. A number of measures taken to the electrodes used in welding, namely recalcination including also at elevated temperature, storage of electrodes in the thermal boxes and also providing the cleanliness of edges of joints to be welded, not always can provide the low levels of hydrogen content.

As is known, according to the Sieverts law the content of hydrogen dissolved in iron is determined by the partial pressure of hydrogen in the gas phase. The source of hydrogen in the weld metal is the electrode coating and the water vapor of ambient atmosphere. As the gas- and slag-forming components the electrode coating includes carbonates $\mathrm{CaCO}_{3}$ and $\mathrm{MgCO}_{3}$ providing protection of the arc zone from ambient atmosphere, fluorspar, quartz sand, rutile, aluminosilicates, etc., as well as alloying components, deoxidizers and processing additives. The mineral components contain different amounts of water impurities in different form [1,2], alloying components - hydrogen [2] in their composition. Together with the moisture of dry residue of liquid glass the total content of hydrogen in the coating is defined as the potential hydrogen $(\mathrm{H})_{\mathrm{p}}$.

During heating of the coating, in the zone of arcing the process of slag formation together with the dissociation of carbonates, a number of reactions in the gas phase and the absorption of hydrogen by the weld pool metal occur [3]. As was established by the experiments and thermodynamic calculations $[4,5]$, in welding under silicon-manganese fluxes the reaction $\mathrm{CaF}_{2}$ and $\mathrm{SiO}_{2}$ with formation of $\mathrm{SiF}_{4}$ followed by the 
Table 1. Data on thermal dissociation of gas molecules and energy of bonds break

\begin{tabular}{|c|c|c|}
\hline $\begin{array}{c}\text { Dissociation } \\
\text { of molecules }\end{array}$ & $\begin{array}{c}\text { Degree } \\
\text { of dissociation } \alpha \\
\text { at } T=3500 \mathrm{~K}\end{array}$ & $\begin{array}{c}\text { Binding } \\
\text { energy } D_{0}, \\
\mathrm{~kJ} / \mathrm{mol}\end{array}$ \\
\hline $\mathrm{H}_{2}=\mathrm{H}+\mathrm{H}$ & 0.282 & 438 \\
\hline $\mathrm{H}_{2} \mathrm{O}=\mathrm{OH}+\mathrm{H}$ & 0.331 & 484 \\
\hline $\mathrm{O}_{2}=\mathrm{O}+\mathrm{O}$ & 0.236 & 494 \\
\hline $\mathrm{HF}=\mathrm{H}+\mathrm{F}$ & $7.2 \cdot 10^{-2}$ & 565 \\
\hline $\mathrm{N}_{2}=\mathrm{N}+\mathrm{N}$ & $1.1 \cdot 10^{-4}$ & 941 \\
\hline $\mathrm{CO}=\mathrm{C}+\mathrm{O}$ & $\sim 1.0^{-10} 10^{-10}$ & 1071 \\
\hline
\end{tabular}

reaction of $\mathrm{SiF}_{4}$ with $\mathrm{H}_{2} \mathrm{O}$ and $\mathrm{H}_{2}$ with formation of fluoride hydrogen gained the noticeable development.

Initially, it was suggested that HF is a very stable compound in the arc gas phase up to $\sim 6000{ }^{\circ} \mathrm{C}$, which allows binding hydrogen and thus reducing the tendency of welds to pores formation caused by hydrogen. Using the new thermodynamic data on the properties of substances, Prof. Frumin [5] noted that $\mathrm{HF}$ is thermally more resistant to dissociation than $\mathrm{H}_{2}, \mathrm{H}_{2} \mathrm{O}$ and $\mathrm{OH}$, and, thus, may lead to reduction of hydrogen content in the weld pool. Applying the mass-spectral method [6], Prof. Pokhodnya and the colleagues established the presence of $\mathrm{SiF}_{4}$ and $\mathrm{HF}$ in the samples of gases evolved during welding using flux-cored wires, and the formation of $\mathrm{HF}$ in the arc discharge in vacuum using the electrode containing $\mathrm{CaF}$ [7]. In work [8] the analysis of influence of temperature of the arc on the strength of diatomic HF, $\mathrm{O}_{2}, \mathrm{H}_{2}$ molecules to the dissociation was carried out and it was shown that at $T_{\mathrm{a}}>3000 \mathrm{~K}$ HF dissociates and is resistant at the arc periphery, where binding of hydrogen can occur.

The data on the thermal dissociation of gas molecules, calculated on the basis of spectroscopic measurements from work [9] and on the energy of bonds break $D_{0}$ from work [10], are presented in Table 1. It follows from them that the degree of thermal dissociation of HF depending on the temperature is somewhat lower as compared to the molecules of $\mathrm{O}_{2}$

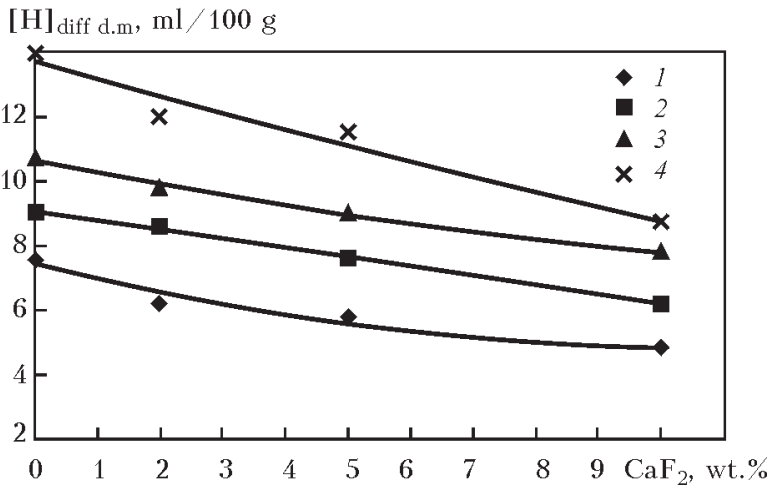

Figure 1. Dependence of $[\mathrm{H}]_{\text {diff dm }}$ content on content of $\mathrm{CaF}_{2}$ in coating composition: $1-0 ; 2-2 ; 3-5 ; 4-10 \%$ of $^{C_{a F}}$ and $\mathrm{H}_{2}$, but significantly higher than that of $\mathrm{N}_{2}$ and $\mathrm{CO}$.

The molecule $\mathrm{N}_{2}$ is more resistant to dissociation as compared to HF. However, both nitrogen and hydrogen are dissolved in iron to a greater extent starting from $\approx 600^{\circ} \mathrm{C}$. According to the data of studies $[11,12]$, during the collision of molecules $\mathrm{H}_{2}$ and $\mathrm{N}_{2}$ against the surface at the appropriate orientation due to the force field of unsaturated bonds of the surface atoms of iron, the dissociation of molecules and transition of $\mathrm{H}$ and $\mathrm{N}$ to the dissolution in the lattice are considerably facilitated. Thus, at the periphery of arc column the process of dissolution of hydrogen, located in compound with fluorine, is also possible, if to compare the energies of bonds break $D_{0}$ and the dependences of dissociation $\mathrm{HF}$ and $\mathrm{N}_{2}$ on the temperature.

According to the data given in Table 1, the most robust molecule is the carbon oxide. The degree of its dissociation at $T=6000 \mathrm{~K}$ amounts to $\alpha \approx 9.59 \cdot 10^{-2}$, i.e. at the arc column temperature $\mathrm{CO}$ is almost not dissociated [13]. The experiments in $\mathrm{CO}$ arc welding [14] showed that the coefficient of elements transition to the weld metal is equal to $0.9-1.0$, i.e. the high energy of $\mathrm{C}-\mathrm{O}$ bond practically ensures its neutrality to the weld pool metal similar to Ar or He.

The thermodynamic analysis of $\mathrm{SiF}_{4}$ formation and its further reaction with water vapors and hydrogen show the possibility of reducing the hydrogen content in the weld metal. The efficiency of $[\mathrm{H}]_{\text {diff d.m }}$ reduction was investigated by introducing of $\mathrm{CaF}_{2}$ and muscovite mica containing $\sim 4.5 \%$ of $\mathrm{H}_{2} \mathrm{O}$ to the composition of coating of experimental electrodes at the content of $46-50 \%$ of marble, quartz sand and muscovite mica in sum of $28 \%$. The calcination of electrodes was carried out at $T=420{ }^{\circ} \mathrm{C}$ for $1 \mathrm{~h}$. Welding of specimens was performed at $160 \mathrm{~A}$ direct current of reverse polarity. The content of $[\mathrm{H}]_{\text {diff d.m }}$ was measured according to GOST 23338 using the chromatographic method. The results of the experiments are given in Figure 1.

According to the obtained data it is seen that with increase in $\mathrm{CaF}_{2}$ content in the composition of coating at the different levels of introduced moisture the content of $[\mathrm{H}]_{\text {diff d.m }}$ decreases. The degree of reduction of $[\mathrm{H}]_{\text {diff d.m }}$ with the growth in $\mathrm{CaF}_{2}$ content is decreased. Such a character of dependence of $[\mathrm{H}]_{\text {diff d.m }}$ content on $\mathrm{CaF}_{2}$ content was obtained in studies $[15,16]$ and is explained by decrease in activity of silica with the growth of $\mathrm{CaF}_{2}$ content.

In the absence of muscovite mica and $\mathrm{CaF}_{2}$ in the composition of coating the content of $[\mathrm{H}]_{\text {diff d.m }}$ amounted to $8.5 \mathrm{ml} / 100 \mathrm{~g}$. The partial pressure of hydrogen $P_{\mathrm{H}}\left(\mathrm{H}_{2}, \mathrm{H}, \mathrm{OH}, \mathrm{H}_{2} \mathrm{O}\right)$ in the gas phase of arc gap was caused by the presence of $(H)_{p}$ in the 
Table 2. $(\mathrm{H})_{\mathrm{p}}$ content in electrode coating components, $\mathrm{ml} / 100 \mathrm{~g}$

\begin{tabular}{|c|c|c|}
\hline Component & $\begin{array}{c}(\mathrm{H})_{\mathrm{p}} \\
\text { as-delivered }\end{array}$ & $\begin{array}{c}(\mathrm{H})_{\mathrm{p}} \text { after calcination } \\
\text { at } 950-1000{ }^{\circ} \mathrm{C}\end{array}$ \\
\hline Quartz sand & 175 & $\sim 10$ \\
\hline Fluorspar concentrate & 340 & $\sim 15$ \\
\hline Rutile concentrate & 490 & $\sim 10$ \\
\hline
\end{tabular}

electrode coating, the products of $\mathrm{CaCO}_{3}$ dissociation and also vapors of the slag melt components. At the introduction of $10 \mathrm{wt} . \%$ of $\mathrm{CaF}_{2}$ to the composition of coating the decrease in the content of $[\mathrm{H}]_{\text {diff d.m }}$ to $4.8 \mathrm{ml} / 100 \mathrm{~g}$ occurs. In this case $P_{\mathrm{H}}$ is additionally reduced due to $\mathrm{SiF}_{4}$ formation through the reaction of $\mathrm{CaF}_{2}$ and $\mathrm{SiO}_{2}$, and $\mathrm{HF}$ formation, which reduces the ability of hydrogen to dissolve in the molten metal as compared to $\mathrm{H}_{2}$ and $\mathrm{H}_{2} \mathrm{O}$ coming from $D_{0}$ values. However, it should be noted that in the reaction of $\mathrm{SiF}_{4}$ formation only a small fraction of the initial amount of $\mathrm{CaF}_{2}$ and $\mathrm{SiO}_{2}$ is involved [17].

To study the possibility of reducing $(\mathrm{H})_{\mathrm{p}}$ ofelectrodes coating and $[\mathrm{H}]_{\text {diff d.m }}$ the hydrogen thermal desorption from a number of components of electrode coatings was investigated using chromatographic method [18]. In Figures 2-5 the results of investigations of thermal desorption of hydrogen from quartz sand, fluorspar concentrate, rutile concentrate and dry residue of $\mathrm{Na}$ glass with modulus equal to 3 , are shown. Heating rate of specimens was $5-7^{\circ} \mathrm{C} / \mathrm{min}$. The content of $(\mathrm{H})_{\mathrm{p}}$ in the components of electrode coating is presented in Table 2.

The content of $(\mathrm{H})_{\mathrm{p}}$ in dry residue of liquid glass, obtained after its drying and calcination at $400{ }^{\circ} \mathrm{C}$, amounted to $530 \mathrm{ml} / 100 \mathrm{~g}$. The content of $(\mathrm{H})_{\mathrm{p}}$ in marble of two fields is given in [19]. Obviously, the water content in the minerals can depend on the fields and technological processing.

The content of $(\mathrm{H})_{\mathrm{p}}$ in the minerals forms a considerable fraction of $(\mathrm{H})_{\mathrm{p}}$ of dry residue of liquid glass. The temperature of electrodes calcination is limited as a rule to $400-450{ }^{\circ} \mathrm{C}$, therefore, from the

Table 3. Influence of heat treatment of electrode coating components on reduction of $[\mathrm{H}]_{\text {diff d.m }}$ content

\begin{tabular}{|c|c|c|}
\hline Electrode & $\begin{array}{l}\text { State of components } \\
\text { for manufacture } \\
\text { of electrodes }\end{array}$ & {$[\mathrm{H}]_{\text {diff d.m }}, \mathrm{ml} / 100 \mathrm{~g}$} \\
\hline \multirow[b]{2}{*}{$48 \mathrm{KhN}-5 \mathrm{AN}$} & As-delivered & $(4.8,4.8,4.8) ; 4.8$ \\
\hline & $\begin{array}{l}\text { After heat } \\
\text { treatment }\end{array}$ & $(3.3,3.7,3.6,2.9) ; 3.3$ \\
\hline \multirow[b]{2}{*}{ Pilot 1} & As-delivered & $(3.9,3.9,3.7) ; 3.8$ \\
\hline & $\begin{array}{l}\text { After heat } \\
\text { treatment }\end{array}$ & $(2.9,2.9,3.1) ; 3.0$ \\
\hline \multirow[b]{2}{*}{ Pilot 2} & As-delivered & $(2.7,2.6,2.6) ; 2.6$ \\
\hline & $\begin{array}{l}\text { After heat } \\
\text { treatment }\end{array}$ & $(2.0,2.0,2.3) ; 2.1$ \\
\hline \multicolumn{3}{|c|}{$\begin{array}{l}\text { Note. In brackets the results of separate measurements are given } \\
\text { without brackets - average value. }\end{array}$} \\
\hline
\end{tabular}

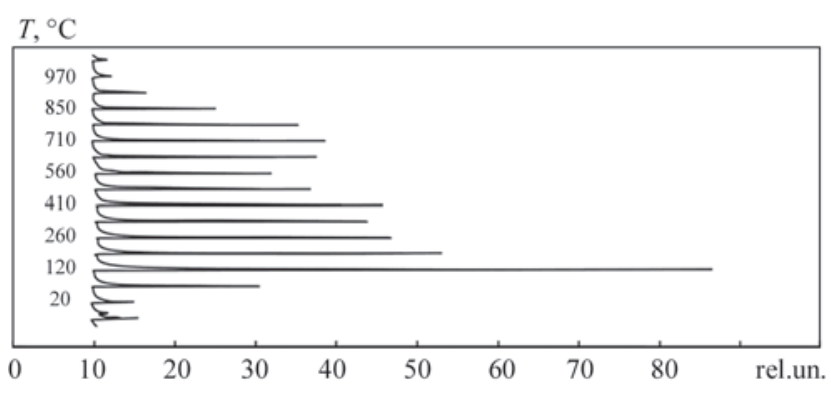

Figure 2. Thermal desorption of hydrogen from fluorspar concentrate

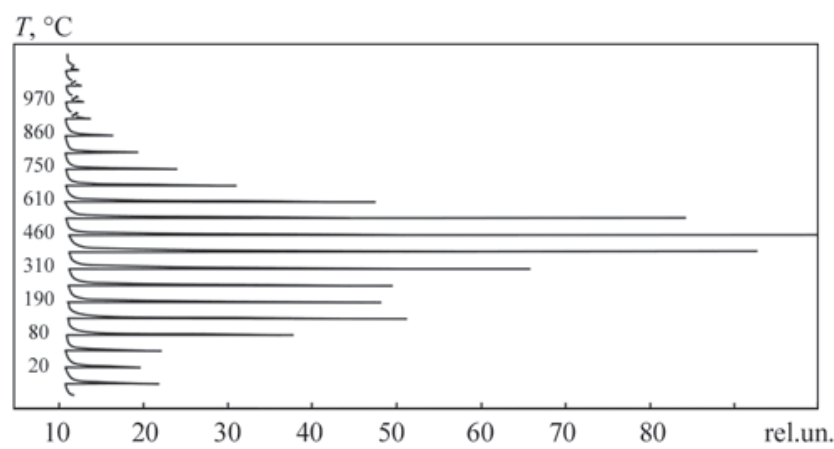

Figure 3. Thermal desorption of hydrogen from rutile concentrate data in Figures $2-5$ it is seen that high-temperature component of $(\mathrm{H})_{\mathrm{p}}$ will also serve as a source of hydrogen. The heat treatment of components at 900$1000^{\circ} \mathrm{C}$ allows reducing $(\mathrm{H})_{\mathrm{p}}$ content (see Table 2).

The efficiency of heat treatment of the components was tested during the development of electrodes designed for welding of high-strength low-alloyed steels. The test results are given in Table 3. Welding

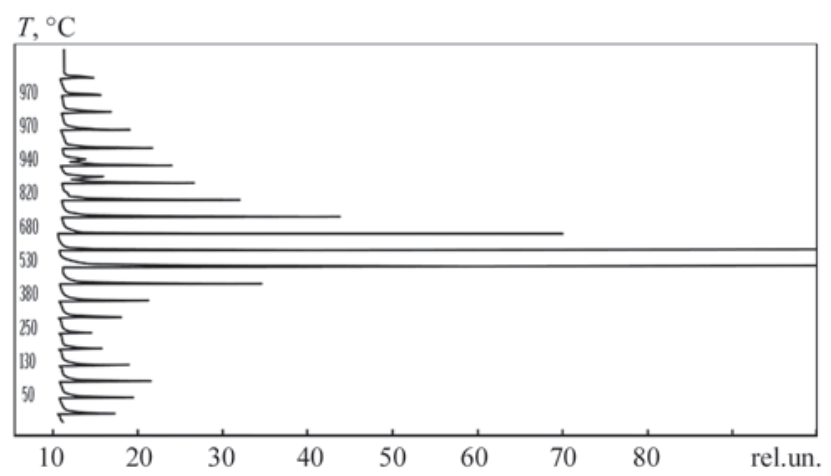

Figure 4. Thermal desorption of hydrogen from quartz sand

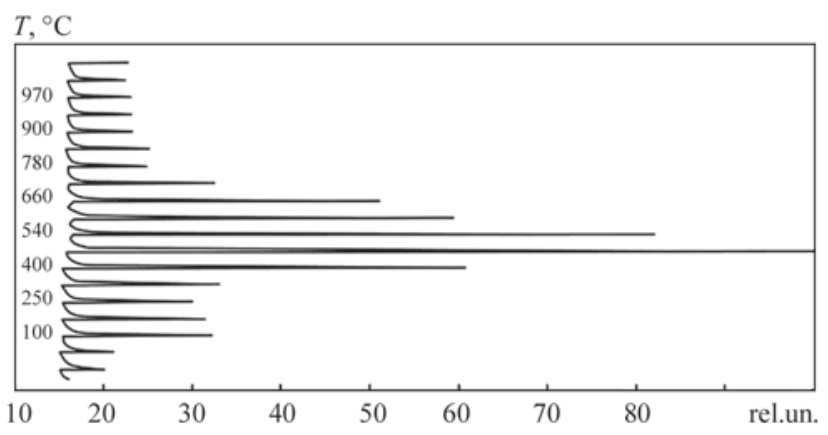

Figure 5. Thermal desorption of hydrogen from $\mathrm{Na}$ glass dry residue 
was performed at 150-160 A direct current of reverse polarity. Temperature of electrodes calcination was $450{ }^{\circ} \mathrm{C}$ during $1 \mathrm{~h}$. The presented results show the influence of heat treatment of components on the reduction of $(\mathrm{H})_{\mathrm{p}}$ content and the ability to provide $[\mathrm{H}]_{\text {diff d.m }}=2-3 \mathrm{ml} / 100 \mathrm{~g}$ depending on the composition of coatings.

\section{Conclusions}

1. The efficiency of reducing the $[\mathrm{H}]_{\text {diff d.m }}$ content in the welds by introducing $\mathrm{CaF}_{2}$ to the composition of electrode coating decreases with the increase in its content and decrease in $(\mathrm{H})_{\mathrm{p}}$ content in the electrode coating.

2. The energy of bond $D_{0}$ of HF molecule can be insufficient to prevent dissolution of hydrogen in the compound with fluorine from the arc gap.

3. The water impurities in the components are not removed completely during calcination of electrodes and they impede the formation of ultra-low hydrogen contents in the weld metal.

4. The reduction of $[\mathrm{H}]_{\text {diff d.m }}$ content in the welds to $3.2 \mathrm{ml} / 100 \mathrm{~g}$ is possible by decrease in $(\mathrm{H})_{\mathrm{p}}$ components of electrode coatings using heat treatment.

1. Betekhtin, A.G. (1950) Mineralogy. Moscow: Gosgeologoizdat.

2. Lushkov, N.A., Razduj, F.I., Shpejzman, V.M. (1959) Hydrogen in welds and its prevention. Leningrad: Sudpromgiz.

3. Pokhodnya, I.K., Gorpenyuk, V.N., Milichenko, S.S. et al. (1990) Metallurgy of arc welding. Processes in arc and melting of electrode. Ed. by I.K. Pokhodnya. Kiev: Naukova Dumka.

4. Kirdo, I.V., Podgaetsky, V.V. (1949) On effect of fluxes on automatic weld porosity caused by rust. Trudy po Avtomatich. Svarke pod Flyusom, 6, 36-62.
5. Frumin, I.I. (1956) Pores prevention in welding and submerged arc surfacing. Avtomatich. Svarka, 6, 1-30.

6. Pokhodnya, I.K., Shvachko, V.I., Ustinov, V.G. et al. (1972) Mass-spectrometric analyses of gaseous fluorides evolving in arc welding. Ibid., 6, 10-12.

7. Pokhodnya, I.K., Shvachko, V.I. (1981) Formation of hydrogen fluoride in arc discharge. Ibid., 2, 11-13.

8. Pokhodnya, I.K., Shvachko, V.I., Utkin, S.V. (1998) Calculated evaluation of hydrogen behavior in arc discharge. Ibid., 9, 4-7, 11.

9. (1964) Reference book of chemist. Vol. 3. Moscow; Leningrad: Khimiya.

10. Gurvich, L.V. (1974) Energy of breaking of chemical bonds. Ionization potentials and electron affinity. Moscow: Nauka.

11. Gerasimov, Ya.I., Dreving, V.P., Eremin, E.N. et al. (1966) Physical chemistry. Moscow: Khimiya.

12. Lakomsky, V.I. (1998) Phenomenological theory of diatomic gases sorption of metal from electric arc plasma. In: Actual materials science of $21^{\text {st }}$ century. Kyiv: Naukova Dumka.

13. Pentegov, I.V. (2004) Generalization of formula of K.K. Khrenov for determination of temperature of welding arc plasma. The Paton Welding J., 8, 48-50.

14. Zameryakin, L.K., Galaktionov, A.T. (1967) $\mathrm{CO}_{2}$-shielded electric arc welding. Avtomatich. Svarka, 6, 74-75.

15. Pokhodnya, I.K., Yurlov, B.V., Shvachko, V.I. et al. (1990) Effect of gaseous fluorides on hydrogen content in welds made by high-efficient electrodes with basic type coating. Ibid., 11, 1-6.

16. Demchenko, E.L., Snisar, V.V., Lipodaev, V.N. et al. (1991) Ways of hydrogen content decrease in weld metal of 03Kh12N8M2GST type in arc welding. Ibid., 10, 23-27.

17. Kuzmenko, V.G. (1980) Peculiarities of reaction of interaction between calcium and silica at $800-1900{ }^{\circ} \mathrm{C}$. Ibid., 6, 33-35.

18. Paltsevich, A.P. (1999) Chromatographic method for determination of hydrogen content in components of electrode coatings. Ibid., 6, 46-48.

19. Pokhodnya, I.K., Yavdoshchin, I.R., Paltsevich, A.P. et al. (2004) Metallurgy of arc welding. Interaction of metals with gases. Ed. by I.K. Pokhodnya. Kiev: Naukova Dumka.

Received 29.12.2015 